DOI 10.31392/NPU-nc.series15.2021.11(143).04

Syrovatko Z.,

senior lecturer at the Department of Health and Sports Technologies

National Technical University of Ukraine "Igor Sikorsky Kyiv Polytechnic Institute"

Yefremenko $\mathrm{V}$.

senior lecturer at the Department of Health and Sports Technologies

National Technical University of Ukraine "Igor Sikorsky Kyiv Polytechnic Institute"

\title{
OPTIMIZATION OF MOTOR ACTIVITY OF STUDENT YOUTH WITH THE USE OF SPORTS GAMES IN THE EDUCATIONAL PROCESS
}

The article states that physical activity has a positive effect on both mental and physical health and is an important, fundamental factor in the formation, maintenance and strengthening. The importance of optimizing the motor activity of students with the use of sports games in the educational process is determined. The necessity of increasing motivation for physical education classes with the help of sports games is substantiated. It is established that motor activity affects a person's social function, in particular, the adaptation to changes in their role in society in old age, provides an opportunity to play a more active role in society. It was found that volleyball and basketball are the most popular sports among modern youth. Motor activity is important in human life, because in the process of evolution it was formed as a biological human need along with the needs for food, water, self-preservation, and so on. It is known that during exercise in the human body certain mechanisms are triggered, as a result of which the functions of not only the muscular system, but also the respiratory, cardiovascular, nervous and digestive systems are strengthened. Despite the fact that today, the promotion of a healthy lifestyle is actively developing, the influence of regular exercise, various sports and moving games is known, the question of increasing physical activity among student youth still remains. As every year there is a tendency to reduce the level of physical fitness, deteriorating health, a phenomenon such is becoming more widespread, which also has a negative impact on the work of students.

Key words: motor activity, sports games, physical education, student youth.

Сироватко 3. В., Єфременко В. М. Оптимізація рухової активності студентської молоді з використанням спортивних ігор в освітньому процесі. В статті визначено, що рухова активність позитивно впливає як на психічне так і на фізичне здоров'я та є важливим, фундаментальним чинником формування, збереження і його зміцнення. Визначено важливість оптимізації рухової активності студентів з використанням спортивних ігор в освітньому процесі. Обгрунтовано необхідність підвищення мотиваиії до занять з фізичного виховання за допомогою спортивних ігор. Встановлено, що рухова активність впливає на соціальну фуункцію людини, зокрема, на пристосування до змін своєї ролі у соиіумі у похилому віці, надає можливість виконувати більш активну роль у суспільстві. Виявлено, що волейбол та баскетбол є найбільш популярними видами спорту серед сучасної молоді.

Ключові слова: рухова активність, спортивні ігри, фрізичне виховання, студентська молодь.

Formulation of the problem. Currently, one of the priorities is not only to preserve the health of children, but their physical development. It is in childhood that children form the foundations of comprehensive motor training and harmonious physical development. One of the main tasks of physical education of children is the diverse development of motor skills. After all, the level of general physical fitness of children is determined by how they are developed basic physical qualities: speed, agility, muscle strength, flexibility, endurance. Sports games and exercises play an important role in the physical education of older preschool children. At any time of the year, they are held mainly outdoors, which is undoubtedly of great importance for hardening and strengthening the health of preschoolers. With their help, children learn a variety of motor skills, acquire moral and volitional qualities: determination, independence, courage, endurance. Games and game exercises and motor tasks are planned throughout the year depending on the season and weather conditions.

Analysis of literature sources. Yu. D. Zheleznyak, A. Belyaev, V. Hnatchuk, V. Platonov, and others. and the generalization of the best experience of training students - volleyball players and their participation in competitions of different levels testifies to the constant growth of competition, which, in turn, puts higher demands on the level of technical, general and special training of volleyball players. These tasks are solved using a comprehensive system approach in the construction of the training process [3]. Various aspects of the researched problem are covered in the works of such scientists as A. Ivoilov, Yu. N. Kleshev, A. Gazhulovsky, S. Ermakov; O. Priymakov, AS Rovny, and V. Platonov were engaged in the study of new movements that presuppose the development of human physical qualities and coordination abilities. The concepts of specialized education in high school were studied by S. Volyanska, V. Lyulka, O. Melnyk, N. Shiyan, etc .; profile training in sports - L. Ivanova, O. Lakiza, S. Operailo, I. Pylypok, O. Plakhotnik, N. Chaprak, etc .. Modern specialists successfully develop new and improve existing methods and means of training and expand the capabilities of the used tools aimed at developing motor skills of higher education students in the process of physical education. However, questions about the peculiarities of the formation of motor activity in students by means of volleyball have insufficient scientific development, which led to the choice of research topic [6].

Presentation of the main research material. In recent years, against the background of intensification of the educational process in higher education institutions, there is a tendency to reduce the physical activity of students, which negatively affects the indicators of their physical condition (E. Zakharina, O. Kuznetsova, etc.). The situation is exacerbated by 
the fact that the traditional form of physical education classes reduces students' interest in regular physical exercise. A significant role in increasing the motivation to use the means of physical culture in higher education is the ability to choose adequate means to compensate for the deficit of daily physical activity [4].

The main approach to the problem of motor activity management is based on the provisions that the tasks and content of the process of physical education to work must meet modern requirements of life. Scientific and technological progress significantly changes the living conditions and activities of people, the pace of life changes, young people lead a more sedentary lifestyle, which negatively affects their health. After all, it is well known the relationship between motor activity and psychophysical state, the lower the level of RA, the lower the level of health, and the worse the psycho-emotional state [2]. One of the effective ways to increase students' physical activity is to involve them in volleyball. After all, among the many sports cultivated in higher education, volleyball has always been very popular among student youth. It is an effective means of physical education, which creates the necessary conditions for harmonious physical development, full recovery, meaningful recreation and leisure of students, their self-realization, the acquisition of healthy lifestyle skills [5].

Scientists emphasize that regular volleyball classes provide the necessary level of motor activity, which has a positive effect on the work of physiological processes, improves the work of all organs and systems of the body of those who play. Volleyball helps to strengthen the health and defenses of the body, improve anthropometric parameters, the functional state of the cardiovascular and respiratory systems and the neuromuscular system [3].

Volleyball forms a healthy lifestyle for young people, attracts them to physical culture and sports. Today, volleyball is becoming especially important for the education and rehabilitation of young people. Therefore, it is important to create organizational and pedagogical conditions for the formation of motor activity in volleyball classes, which contribute to the construction of the educational process of physical education.

Taking into account the needs, interests, capabilities of students, their readiness for the systematic implementation of physical culture and health activities. Volleyball is one of the most affordable sports, which is an excellent way to attract young people to regular physical culture and sports, to active recreation. This game unites both peers and people of different generations. Another important feature of the game is the variety of motor actions that have an active impact not only on all muscle groups, organs and physiological systems, but also on moral and volitional qualities. The need to agree with the established rules of the game has a great impact on the human psyche. Being on the field, players feel the spirit of rivalry. And the game with victory, as you know, causes a storm of positive emotions [1].

Volleyball has a positive effect on the cardiovascular and respiratory systems, strengthens the skeletal system, develops joint mobility, increases muscle strength and elasticity. Constant interaction with the ball helps to improve deep and peripheral vision, accuracy and orientation in space. An instantaneous reaction to visual and auditory signals develops [6].

The peculiarity of the game of volleyball is the simple equipment: a small playground, net, ball. The rules of volleyball include the need to keep the ball in the air and, passing it to each other, to provide a more comfortable position, include various short runs, jumps, receiving the ball on the floor. With regular volleyball classes not only increases the physical activity of students, but also there is a powerful incentive to involve them in a healthy lifestyle, active, regular physical activity. The development of such qualities as speed, agility, speed of thinking, coordination help to achieve high results in other sports [6].

Each game has a specific goal, striving to achieve which its participants have the opportunity to creatively express their capabilities, their inner "I" and generally assess their strengths. In volleyball, everyone can show the best features of their temperament and character, natural abilities, develop a unique individual style of play, find a creative solution to standard problems. Playing volleyball requires players to show maximum physical ability, willpower and the ability to use the acquired skills, as well as the ability to maintain them. Positive emotions are revealed: cheerfulness, cheerfulness, desire to win. A sense of responsibility develops, as each of the players performs a certain mission in this game. The spirit of the team and the speed of decision-making is the basis on which the whole game is built. Due to its emotionality, playing volleyball is a means not only of physical development, but also of active recreation [8].

The game of volleyball is characterized by a rich and varied motor content. To play volleyball, you need to be able to run fast, instantly change the direction of movement and speed, jump high, have strength, agility and endurance [7]. Qualitative changes also occur in the musculoskeletal system of those involved. As a result of performing a large number of jumps during blows and blocking, the skeletal system is strengthened, joints become more mobile, muscle strength and elasticity develop. Constant exercises with the ball help to improve deep and peripheral vision, accuracy and orientation in space [6].

Research has shown that students who play volleyball outperform their peers in terms of growth. Volleyball classes promote the development of many physical qualities. A variety of jumps, performing techniques of the game in the fall develop the strength of the muscles of the legs, torso and arms. In volleyball, strength is manifested along with a high rate of muscle contractions. This in turn leads to the development of speed, which contributes to the mastery of volleyball techniques [5].

Due to insufficient motor activity, the strength and efficiency of skeletal muscles are reduced. This leads to postural disorders, curvature of the spine, flat feet, delayed age-related development of physical qualities. Prolonged stay in a monotonous position causes a static load on certain muscle groups, which leads to their fatigue and exacerbates the adverse effects of hypokinesia [4].

The influence of exercise on the nervous system is the development of coordination of various movements, regulation of the functions of the cardiovascular and respiratory systems, in the training of adaptive mechanisms. In addition, when muscles work from them, a powerful flow of nerve impulses enters the central nervous system, which is extremely important for maintaining its tone. Moderate physical activity on the endocrine glands, whose hormones together with the nervous system are the basis of adaptation mechanisms, has a stimulating effect [6].

Thus, the body's resistance to adverse environmental factors increases: stressful situations, high and low 
temperatures, radiation, microorganisms that cause colds and more. During physical activity, the muscles of the diaphragm contract more often (due to increased respiratory rate), as well as the muscles of the anterior abdominal wall, which improves the functioning of the gastrointestinal tract. Increased secretion and secretion of bile from the liver, which improves its function. As a result, the blood is better cleansed of toxic substances, proteins, enzymes and vitamins necessary for the body are synthesized better.

Frequent change of game situations develops the ability to quickly master new movements and instantly restructure motor activity. As you master the techniques of the game, the coordination difficulties faced by the volleyball player gradually increase: you need higher accuracy, their mutual coherence, the ability to respond to sudden changes in the situation, the need for repeated techniques, bringing them to automatism, requires endurance. In this regard, it is important to educate strong-willed qualities, the ability to force themselves to continue working with a given intensity, despite the difficulties [3].

Due to its accessibility and emotionality, volleyball not only serves physical development, but also is a means of active recreation. Proper organization of volleyball and competitions are of great educational importance. Physical activity of volleyball players, although characterized by high intensity, almost completely eliminates high running loads. Thus, the study of motor activity of students showed that this issue is still relevant, because the level of motor activity remains quite low and the situation is getting worse every year. One of the most effective ways to increase physical activity is the gym enrollment of students of higher education institutions in volleyball classes. The game activity in volleyball is characterized by rapidly changing conditions of struggle on the court, which are under the constant control of the opponent, who in turn tries to destroy the defense of opponents, not only quick reactions, but also high motor activity.

Physical education is the only academic discipline in higher education institutions, aimed at attracting students to a healthy lifestyle, the formation of general and professional culture of the modern specialist, improving the physical and psychophysical condition of students. Physical education of student youth is a holistic specialized process in which physical development is combined with mental education and upbringing, which aims to meet the needs of both the individual and society as a whole in the formation of a fully developed person, highly qualified specialist capable of successful professional activity. The importance of physical activity is especially growing in modern conditions of society, when due to a sharp increase in the complexity of the educational process in general secondary education, the introduction of a multilevel education system in higher education, and mass computerization reduces physical activity of children, adolescents and young people. Especially students of higher education institutions.

Properly organized and individually dosed motor activity has a positive effect on the physical condition of students, in particular, expands the functional and adaptive capabilities of the cardiovascular, respiratory and other systems, improves redox processes, also increases the total lung capacity, is physiologically appropriate development of the capillary system, helps to increase the overall adaptability of the organism to adverse environmental factors.

Conclusions. Analyzing the scientific and methodological literature on this issue, it should be noted that the level of development of motor activity in students of volleyball also depends on the possession of students' technical and tactical skills. The higher the level of development of special qualities and abilities, the faster you can master the basics of technique and tactics of the game. Skillful, correct selection of methods, principles and tools used in the classroom will help to form skills in mastering techniques and tactics, will promote the development of physical and moral qualities of the student, which will increase motivation and improve the level of motor activity.

\section{Reference}

1. Averin I. V. (2000) Special training of a volleyball player / I. V. Averin // Sport at school. - №11. - p. 9-16.

2. Belousov A. Z., Rybakova L. A., Sarkisyants E. E. (1974) Some social factors of students' health // Questions of hygiene and health of university students: Sat. scientific. tr. M. - S. 6-8.

3. Bubley T. A. (2015) Differentiation of physical science has the right to scientists of special medical groups as a strategy of protecting the health of students. T. A. Bubley, O. Yu. Putrov // Scientific Hour Writing Series 15 "Scientificpedagogical problems of physical culture / physical culture and sport /" P. Dragomanova.-- S. 75-77.

4. Bubley T.A. Methodology of differential education of physical scientists has the right of primary school scholars with health outcomes: author. dis. ... Cand. ped. Sciences: [special] 13.00.02 «Theory and the technique of navchannya (physical culture, bases of health)» / Bubley Tetyana Anatoliïnna; Nat. ped. un-t im. M.P.Dragomanova. - Kiev, 2018 .-- 19 p.

5. Demchishin A. (1989) Training of volleyball players / A.Demchyshyn, B.Pylypchik. - K .: Health. - 154 pp.

6. Linetz M. M. (1997) Fundamentals of the method of development of motor qualities: teach. manual / M.M. Linetz L. : Staff. - 207 pp.

7. Vilensky M.Ya. (1982) Physical culture in the scientific organization of the learning process in higher education: Textbook. allowance. M.- $156 \mathrm{p}$.

8. Volkov L. V. (2002) Theory and methods of children's and youth sports: a textbook / L.V. Wolves. - K .: Olympic literature. - 296 p. 